\title{
Managing and Training of Human Resources in Hotel Micro Business, Case Study: Peja City
}

\section{Phd(c) Merita Begolli Dauti}

University "Haxhi Zeka". Kosovo merita_dauti@hotmail.com

\section{Doi:10.5901/mjss.2015.v6n2s2p141}

\section{Abstract}

Tourism presents very complex activity with social-economic character which has diverse importance in activities and economic branches that is very important activity in economy of our country, and on last years is becoming an important sector of economy. Development and quality is not possible without human resources. Main factors of success in tourism are human resources which through training get perfection and get qualified in the industry of tourism and hotels. To manage one hotel presents difficulty and different pleasure which should be balanced to achieve full service. A good managing is difficult to assess in short term since it has to go through a long process of the offering service, its consuming and at the end to listen to the opinion of clients for the offered service, their pleasures and disappointments. This project is based at the empiric data through questionnaires in which were surveyed micro business hotels. The aim of this project is to provide empiric proves regarding training of human resources in Kosova micro business. Data are collected surveying managers of business hospitality using closed questions and on likerts scale. Collected data show that managers of micro business hotels in our country are aware that training of human resources is important and completes the needs of one business, while on the other hand they do not apply greatly different trainings of human resources during their work activity on their business.

Keywords: Tourism, Hospitality, Managing, Training, Micro-business

\section{Aim of research}

Aim of this project is how to implement training of human resources and the importance that managers of micro business in our country pay.

\subsection{Objectives of the research}

Having in mind the character of this project, attention was focused in implementation of these goals:

$>$ Reviewing of the literature for managing and training of human resources and the models that are being used for managing of the human resources. This context would serve as theory context to base the work analyses.

$>$ Conducting of questionnaire in micro business hotels to identify what manager's think regarding the training of human resources.

$>$ Conducting of data analyses based in quality and statistic information combining methods of statistical analyses with a quality ones.

$>$ Presenting of a set of conclusions of the project, giving some explanations regarding matters that are object of study in this project.

\subsection{Hypothesis}

"Still we do not have proper awareness of managers for importance of training of human resources in micro business hotels".

\subsubsection{Methodology used in the research}

For realization of this study was used methodology that consists with one combination of primary data with the second ones. A significant proportion of secondary data were provided through the use of electronic libraries and managing literatures. Also were used data of the studies that were done by the Ministry of Trade and Industry for the profile of 
tourism sector in entire Kosova. To see how important training of human resources in micro business hotels is we have designed a questionnaire. Questionnaires are with closed questions and with likerts scale. This questionnaire was directed to the managers of micro business hotels. Questionnaires were distributed to 200 businesses during year 2014, while 193 answered. Distribution of questionnaire was done personally interviewing the manager of business hotel

\subsubsection{Importance of the study}

Importance of this study I think is greater because first of all helps to all managers in tourism and hotel sector because the level of quality of service depends from the quality of staff. Qualities connect with knowledge, skills and opinions or ideas which influence in surviving and developing of a hotel business. For this reason training of the staff is essential in many ways. It increases productivity in meanwhile that employees are "armed" with professional knowledge, experience and valued ideas.

\section{Introduction}

Historically term "human resources" was determined as a working strength and was listed among four main factors of the production: land, working strength, capital and costs. This training of employees is a source as financial sources or those physical ones which has genesis at the politics of the employees during industrial revolution. Managing of human resources came as consequence of the fact that organizations requested from employees to work and produce more than they were rewarded. (Appelbaum, E., Bailey, T., Berg, P. and Kalleberg, A (2000).

Meaning of human resources changed as year passed by because the concept of organizations expanded and employees started to be treated more as human beings and not as live materials or organizational systems. Human resources started to be noticed as dynamic and flexible resources so the organizations started to search for different manners with intention to motivate them and to increase performance, this made the increase researches in area of human resources and lately the information is getting provided also from the science of physiology, economy and economic politics. (Fisher, D. 1989)

Concept of human resources expanded by the term of managing of human resources in development of human resources which has to do with support and skills that are being given to the employees not only to perform their job but also to get prepared for the rise of their carriers. Human resource management went through a long process of development until it reached the status that gained today, one of the most important functions of managing in one organization. (Koli.Z, Llaci.Sh, 2005).

\subsection{Managing of human resources}

Every organization, enterprise or institution that aims to fulfill their goals should engage in providing not only technical or financial resources but also of the human resources which have ethical importance for the success of the organization. Resources or human assets are those that project the best and services, check the quality, trade products and take decisions for the manner of organization functioning. Managing of human resources thru activities helps to the management of organization for the effective use of their employers. It includes activities as: selection and employing of people, evaluation and their rewarding, creating conditions for them to be motivated more for work.

As Gary Dessler described "HRM is the policies and practices involved in carry out the "people" or human resource aspects of a management position, including recruiting, screening, training, rewarding and appraising." These practices and policies include conducting job analysis, selecting suitable and required candidates, orienting new employees, plans and implementation of training and developing, managing salaries, providing employees" benefits and awards etc. (Dessler 2006, 4)

HRM is a pattern of planned HR development and activities which affect the behavior of individuals with the intention of enabling organizations to achieve their goals (Wood, Holman \& Stride, 2006).

HRM refers to the policies, practices, and systems in organizations for recruiting and developing their employees, as well as influencing their behavior, attitudes, and performance to achieve the organizations' goals (Stone, 2008).

HRM competency contains an organizations' ability to recruit, train and develop, maintain and utilize prospectoriented employees with their capacities in a way that they comply with their organizations' goals (Zaugg \& Thom, 2003).

Human resource management is defined as 'a strategic and coherent approach to the management of an organization's most valued assets-the people working there who individually and collectively contribute to the achievement of its objectives'(Armstrong, 2006). 
Bartol and Martin (1998), also state that human resource management is the management of various activities designed to enhance the effectiveness of an organizations' workforce to realize set goals.

\subsubsection{Training}

Activities of development of human resources were traditionally qualified under the presidencies of training, development and education. Training is a planned activity performed in short term to highlight specific knowledge regarding work, attitude and skills. Education is long term process applying general knowledge and often not connected to work. Both can contribute in individual development: improving and general increasing of skills of an individual through conscious and non-conscious learning (Buckley and Caple, 2004).

Training of the employees is a learning experience, whose intention is to achieve a change relatively stable improving their skills of performance during work. In this way training includes changing of qualifications, of knowledge, of attitude or of behavior (C.S.Duncan; J.D.Selby; W.Swart, 2002).

Training is the process of developing knowledge and expertise in people, (Swanson, R. and Holton, E., 2001).

Training and learning should result in change in attitude or an acquisition of new skills. Honey and Mumford (1996) explains that learning or training can only be said to have taken place when people can demonstrate that they know something that they did not know before (insights, facts and realizations) and when they can do something they could not do before (skills). Training is job or task oriented. It therefore aims at enabling individuals to perform better on the job they are currently doing.

Armstrong, M. (2006) defines training as a planned and systematic modification of behavior through learning events, programs and instruction, which enable individuals to achieve the levels of knowledge, skill and competence needed to carry out their work effectively.

The Number of Registered Businesses in the Tourism Industry in 2013 it was ( 2,089): (1,938 Micro), (141 Small), (9 Medium) and (1 Large Company)

\section{The basic data for the hotel business}
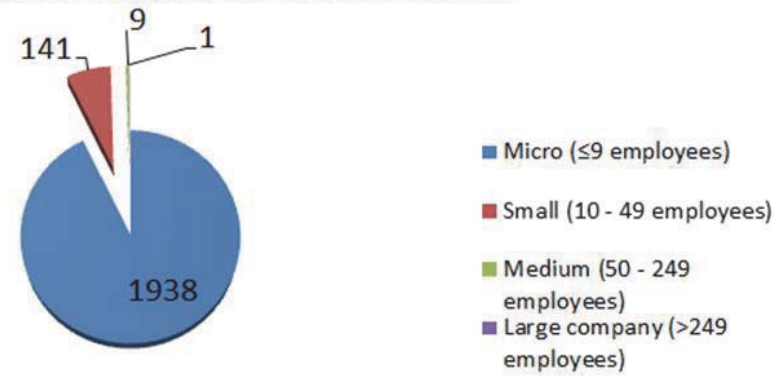

The distribution of businesses by region

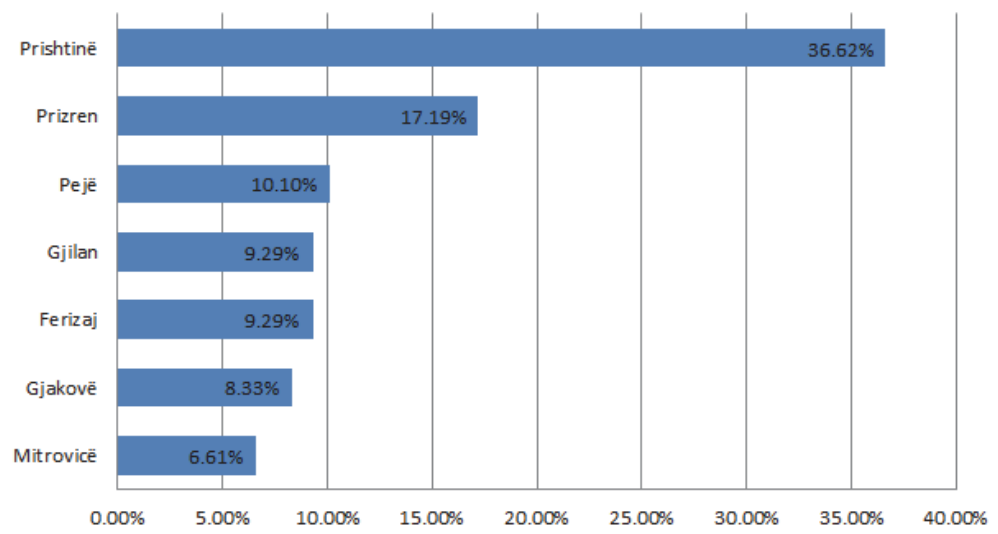

Source: Tax Administration of Kosovo ,2013 
This Part of Questions Requires Getting Basic Information for Managers of Micro Business Hotels

\section{Gender}

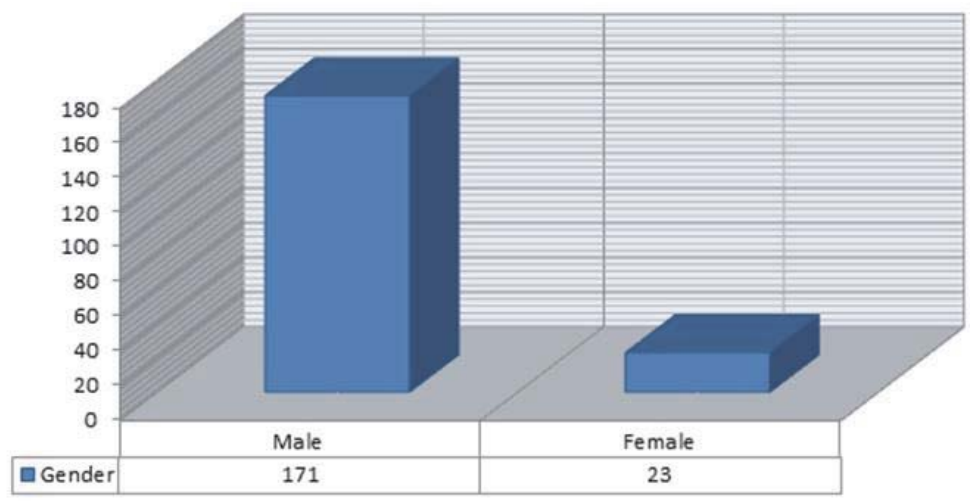

\section{Age}

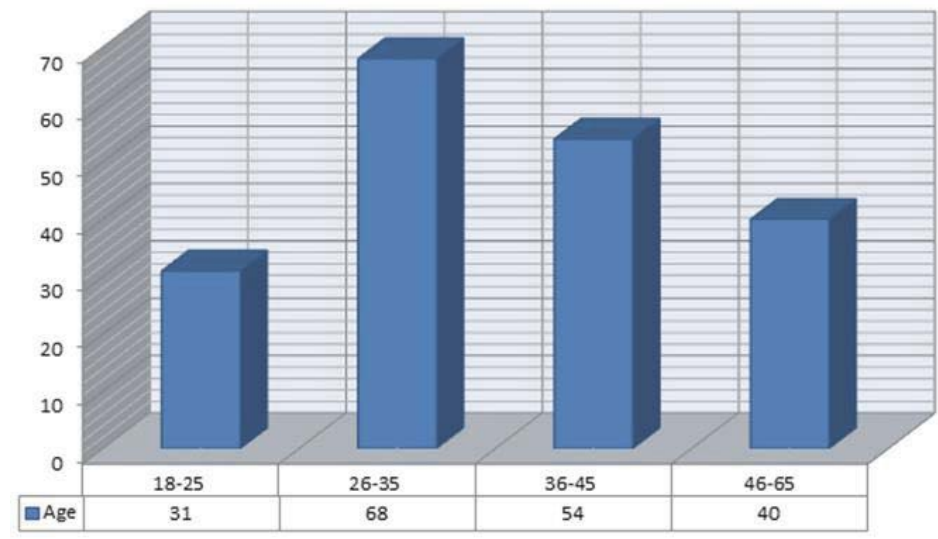

3. Education: Which is your Level of Education?

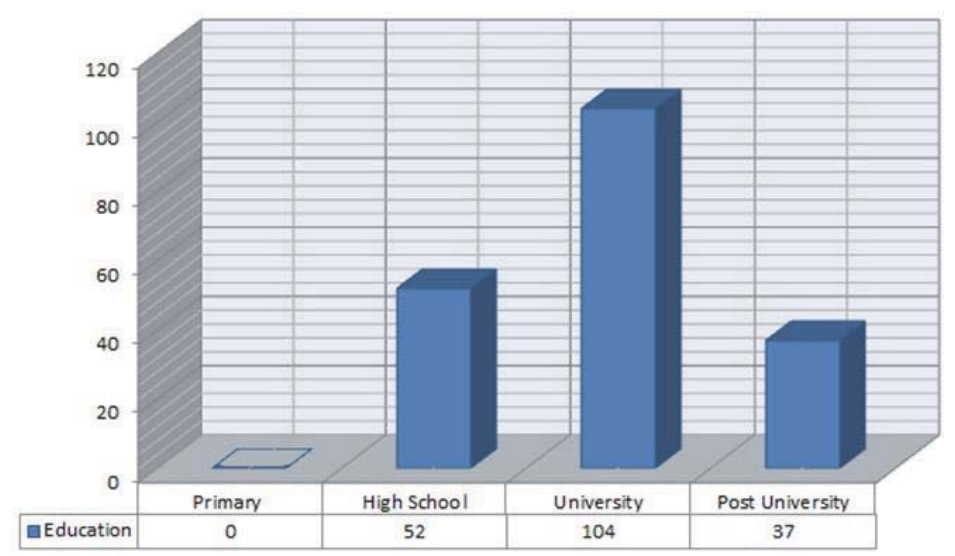


4. Your Work Experience in Business Hotel?

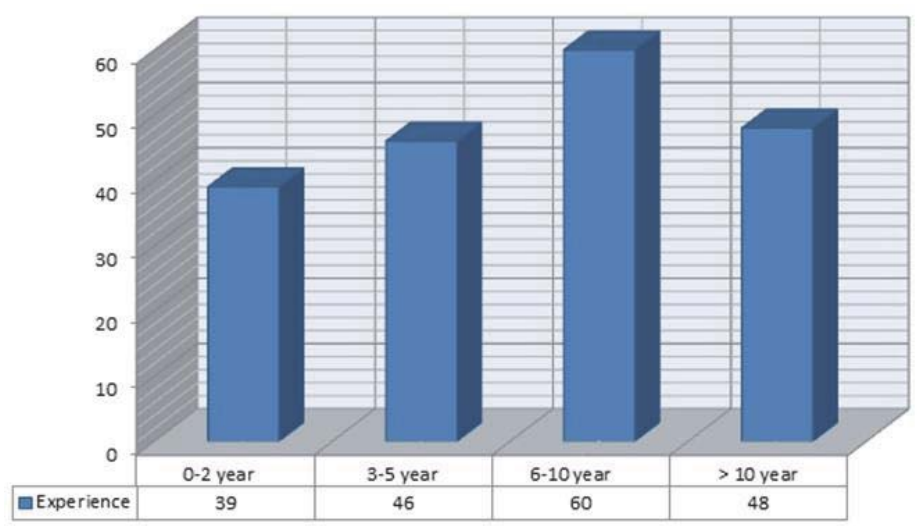

5. How often you have Training of your Staff in your Business?

\begin{tabular}{|c|c|c|c|c|}
\hline \multirow{2}{*}{5} & \multirow{2}{*}{ Have you been trained for the hotel when you started working? } & Yes & 46 & $24 \%$ \\
\hline & & No & 147 & $76 \%$ \\
\hline \multirow{4}{*}{ 5.a } & \multirow{4}{*}{ If yes, for how long? } & 1-weekly & 14 & $30 \%$ \\
\hline & & 1-monthly & 26 & $57 \%$ \\
\hline & & 3-monthly & 6 & $13 \%$ \\
\hline & & More then 3 month & 0 & $0 \%$ \\
\hline \multirow{4}{*}{ 5.b } & \multirow{4}{*}{ What do you train? } & General knowledge about hotels & 13 & $28 \%$ \\
\hline & & Customer service & 7 & $15 \%$ \\
\hline & & Using computer system & 26 & $57 \%$ \\
\hline & & Department manager & 0 & $0 \%$ \\
\hline \multirow{4}{*}{ 5.c } & \multirow{4}{*}{ How was the first training when you take part? } & Important & 27 & $59 \%$ \\
\hline & & Necessary & 19 & $41 \%$ \\
\hline & & Just a routine & 0 & $0 \%$ \\
\hline & & Not important & 0 & $0 \%$ \\
\hline
\end{tabular}

These Questions Require Necessary Information by Managers of Micro Business Hotels for Staff Training

\section{How often have you Training your Staff in your Business?}

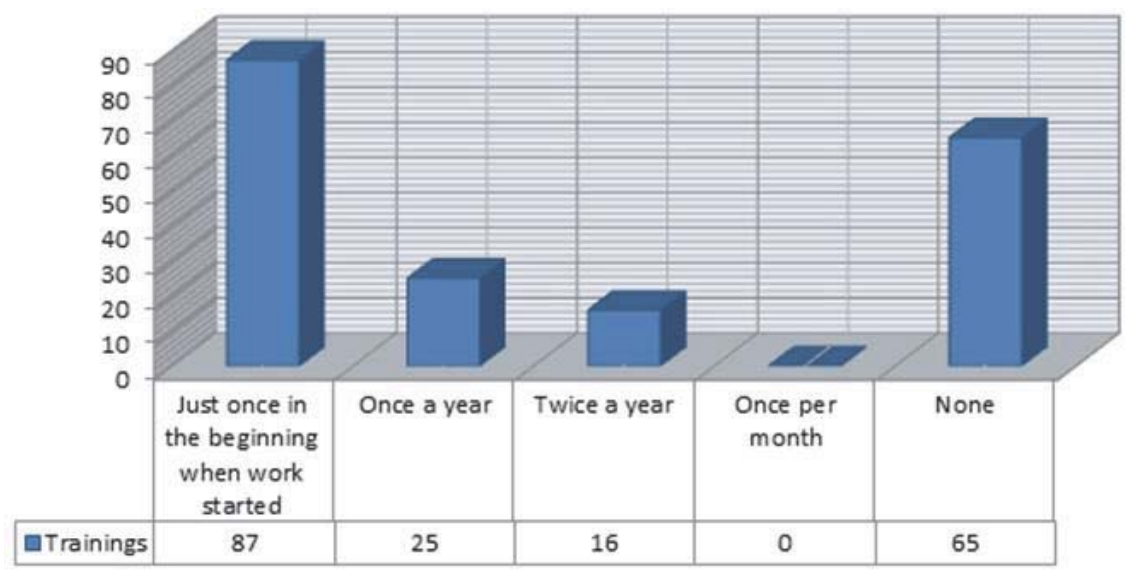




\section{Trainings of Business Staff of Hotels are:}

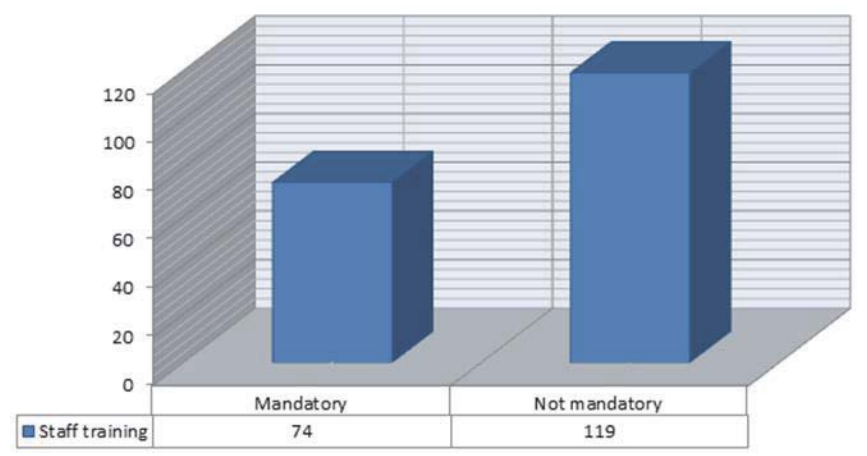

\section{Do you have to Search for a Trainer for Training of your Staff?}

\begin{tabular}{|c|c|c|c|c|}
\hline \multirow{2}{*}{8.} & \multirow{2}{*}{$\begin{array}{l}\text { Do you have to search for a trainer for training of } \\
\text { your staff? }\end{array}$} & Po & 74 & $38 \%$ \\
\hline & & Jo & 119 & $62 \%$ \\
\hline \multirow{2}{*}{ 8.a } & \multirow{2}{*}{ Where do you held trainings for your staff? } & Within the business & 49 & $66 \%$ \\
\hline & & Outside business & 25 & $34 \%$ \\
\hline \multirow{4}{*}{ 8.b } & \multirow{4}{*}{ Who held trainings for your staff? } & $\begin{array}{l}\text { Specialized trainers for field of hotels from the } \\
\text { countries that have developed tourism. }\end{array}$ & 7 & $9 \%$ \\
\hline & & Hired lecturers from the country and from abroad & 6 & $8 \%$ \\
\hline & & Managers & 49 & $66 \%$ \\
\hline & & Trainers and supervisors & 12 & $17 \%$ \\
\hline
\end{tabular}

\section{Why Training is Important for Business Hotels?}

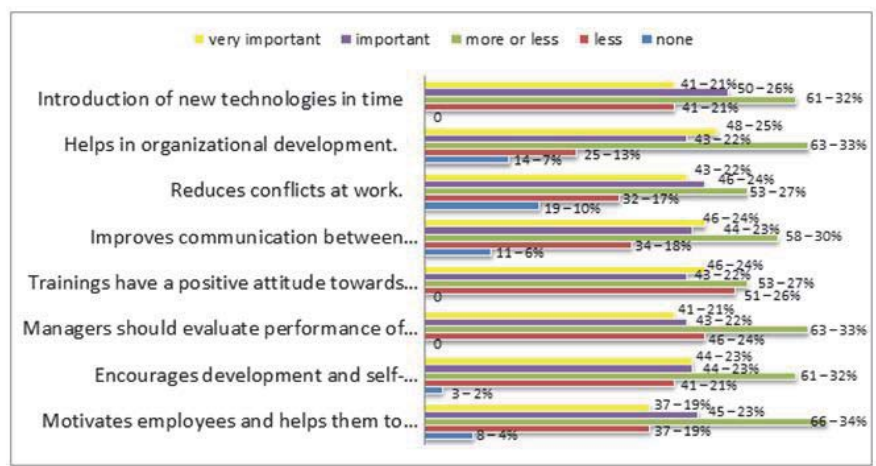

10. How would you be Satisfied if you would have Specialized Trainers in Field of Hotels for the Training of your

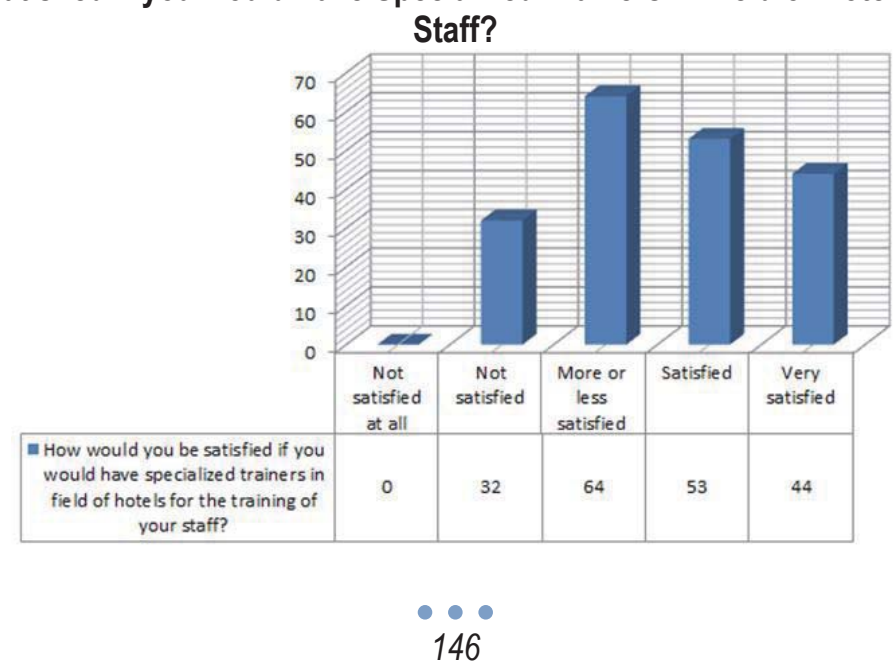




\section{Data Analyzing}

During primary research achieved for aims of this project were taken sufficient data by the questionnaires with a sample from 193 micro business hotels that operate in Peja town.

This part of questions requires getting basic information for managers of micro business hotels

Total number of manager's male gender was 171 , while female gender 23. Majority of them 65 were aged 26-35 while the other part had different ages. Level of their education in majority was university degree, 37 were post graduated, and with high school 52 managers. Majority had experience in business hotel 6-10 years while others had less. Majority of managers 147 were not trained at all in the area of catering (hotels) when they started their business while 46 were trained.

These questions require necessary information by managers of micro business hotels for staff training

Training of staff in business hotel in major number 87 had training just once when employees started to work while 65 answers were that their staff never participated in trainings. Managers in majority 119 think that training is not mandatory in their business while 74 think that are mandatory. Need for the training for training staff was not awareness rising of managers where 119 think there is no need to request it while 74 of them answered that there is a need to request it. As for importance of trainings most of them majority answered until certain point while answers of managers for specialized trainers in area of catering (hotels) for training of their staff in their businesses were satisfied until certain point 64 managers, satisfied were 53, very satisfied 44 and not satisfied 32.

Based to analyses of questionnaires and raised hypothesis in the project:

"Still we do not have proper awareness of managers about the importance of human resource training in microenterprises hotels".

We came to the conclusion that hypothesis was verified for the reason that 119 surveyed managers were not interested for the importance of staff- human resources training in their businesses.

\section{Conclusion}

As in most other businesses human resource management is the most complex and difficult process for managing a hotel. Managers require a sustained and optimal performance of employees because it is directly related to the importance and their interaction with customers. As a result, managers and their organization seek to secure the environment, reward and motivation towards workers that make them valuable to increase the performance and delivery of the satisfaction to customers. In modern business hotel is everything based on the competence of the people and especially the qualities and characteristics of employees. The level of quality of service depends on the quality of staff. Qualities are related to the knowledge, skills and thoughts or ideas that affect the survival and development of a hotel. For this reason, staff training is essential in many ways. It increases productivity while employees are 'armed' with professional knowledge, experience and valuable ideas.

Training of staff also motivates and inspires employees providing them all necessary information at work and also helps them understand how important is work that they will perform.

Need for training can arise for many reasons as for example (Llaci, Shyqyri \& Koli, Zana, 2005):

- When employees start to work in one hotel should learn secrets of work, to learn how the work is being done in new environment.

- Even that new employers were selected based to qualifications and main characteristics they can again have a lack of ability.

- $\quad$ The reorganization of work may require the employee to acquire more capacity.

- If employees are promoted or transferred they need more capacity.

\section{Recommendations}

From the conducted study we concluded that with all the changes that occurred these last years in Kosova and in specific way in Peja we still don't have an awareness of managers for the importance of function of management. Some of the reasons why management of micro businesses is not developed in city of Peja we can find also in development of personnel also in problems with which were faced these companies during the period of transition. Successful hotels always include staff training as one of the key parts of the strategy development. Sorted by composition of training they are held for different purposes, some are getting organized to help the new employees to know the hotel, while some other are being attended to develop skills and knowledge of current employees. 
So based to recommendations every hotel business should be refrained to these types of trainings (Yang. Xiao,

- Initial training: This training helps to introduce general hotel information and based skills needed for work. It promotes building good relations between employees as well as among employees and management also. Above all, this type of training helps employees develop the appropriate behavior towards work that they will carry.

- Training through testing and obtaining certificates: After this kind of training, workers receive a professional certificate or any theoretical test. This training is intended to promote the skills and motivation of employees when they are able to take this exam.

- Training as work practice: Professional skills of the employees is the key of the service of one hotel, work rules and principles are taught in this kind of training, except the courtesy, manners and techniques of maintaining interpersonal relationship. It aims to train employees to learn how best to do the job as effectively and quickly as possible.

- Language training: The hotel staff should have as basic skills recognition of one or more foreign languages for different departments, different categories of jobs or different positions. English as a used international language should be known by all staff. While the knowing of a second language would depend from the location of the hotel that in our country is Albanian language.

\section{References}

Appelbaum, E., Bailey, T., Berg, P. and Kalleberg, A (2000). Manufacturing advantage: why high performance work systems pay off. Cornell University Press, Ithaca, NY.

Armstrong, M. (2006), A Handbook of Human Resource Management Practice 10th .Ed. London: Kogan Page Ltd

Bartol, K.M., and Martin, D.C., (1998). Management. New York: McGraw-Hill Companies

Duncan, C. S., Selby-Lucas, J. D., Swart, W. (2002). Linking Organizational Goals and Objectives to Employee Performance: A Quantities Perspective. Journal of American Academy of Business, 314-318.

Fisher, D. 1989. Current and Recurrent Challenges in HRM. Journal of Management. Vol: 15 pg. 157-178.

Gary, Dessler 2006. A Framework for Human Resource Management. 4th edition.New Jersey. Pearson Prentice Hall.

Honey, P and Mumford, A (1996) The Manual of Learning Styles, 3rd edn, Honey Publications, Maidenhead.

Human resource management - organisational development - knowledge creation.Journal of Change Management, 3(3), 199 - 211.

Koli, Z. \& Llaci, Sh. (2005). Menaxhimi i Burimeve Njerezore. Tirane.

Llaci, Shyqyri \& Koli, Zana, Manaxhimi i Burimeve njerëzore, Kap. IX 'Trajnimi' Fq. 251.

Roger Buckley \&Jim Caple "The Theory and Practice of Training", London.2004.

Stone, R.J. (2008). Human Resource Management (6th edition). John Wiley \& Sons, Australia.

Swanson, R.A., and Holton III, E.F., (2001). Foundations of human resource development.1st ed. San Francisco: Berrett-Koehler publishers.

Wood, S., Holman, D., \& Stride, C. (2006). Human resource management and performance in UK Call Centres. British Journal of Industrial Relations, 44(1), $99-124$

Yang Xiao, The importance of staff training in the hotel industry, fq.25, Business economics and tourism, 2010.

Zaugg, R. J., \& Thom, N. (2003). Excellence through implicit competencies: 